\title{
Risk factors in the process industry by using MCDM methods: Literature from 2014 to 2019
}

\author{
R.K.A.Bhalaji, S. Bathrinath, S. Saravanasankar
}

\begin{abstract}
Risk factors act as a critical part in the process industry because it affects the production efficiency, turnover and industrial development. Both managers and employees from industry faces the risk and difficult to manage them. So, the main aim of the review paper is to identify the most influential risks in the process industry by using Multi-Criteria Decision Making (MCDM) methods. But many employees have illiterate and poor knowledge about the risks. To overcome this issue, based on the risk percentage we prioritize the risks. For the employee's perspective, it is easy to know and understand about the risks, how to handle the risks and to take preventive action before the risk will happen. The result of the review paper shown that $40 \%$ of risks occurred in sustainability, therefore more attention should be given to the risks by implementing some norms and standards regarding social and environmental issues.

Keywords: MCDM, Risk Factors.
\end{abstract}

\section{INTRODUCTION}

$\mathrm{D}$ evelopment of industry is very essential one in the rising nations like India. Process industry plays a major role for industrial improvement in the nation because they give employment to the most of the people. Process industries are almost located in southern region of India in which most of the employees are lack of knowledge about risks. They are not aware about how to handle the most influencing risks and also compared to other industries risk factors are very high in process industries [1]. For this purpose, the main aim of the review paper is to identify the most influential risks in the process industry by using MCDM methods. Based on the results, prioritize the risks based on the risk percentage it will be helpful for both management and employees to understand about the risks. Before starting a manufacturing process, industries can use the outcomes for reducing the risks by implementing some technologies and standards. For protecting the employees from risks in the working environment, management provide some protecting equipment and give some tips about suitable control measures for avoidance of risks in the working environment. Every process industry should follow rules and regulations of government by implementing ISO and environmental standards, management system, disposal and segregation

Revised Manuscript Received on December 5, 2019

* Correspondence Author

R.K.A.Bhalaji, Department of mechancical engineering, Kalasalingam Academy of research and education, Krishnankoil-626126, India. Email: bhalaji28@gmail.com

S.Bathrinath*, Department of mechancical engineering, Kalasalingam Academy of research and education, Krishnankoil-626126, India. Email: bathri@gmail.com

S.Saravanasankar, Department of mechancical engineering, Kalasalingan Academy of research and education, Krishnankoil-626126, India. Email: ssaravanasankar@klu.ac.in

methods and quality of the service. In this review paper, we use MCDM methods for identifying the most influential risks and also many review papers are explored by using MCDM methods [2,3]. From the previous reviews, we identified the most influential risks in the process industry are sustainability, supply chain, waste management, green supply chain and service quality. For achieving the production efficiency, turnover and improvements this outcomes will surely useful for this industry.

\section{MAJOR RISKS IN THE PROCESS INDUSTRY}

\section{A. Sustainability}

Kumar et al. [4] conducted the review for development of sustainability by using mcdm methods and they said that it is easy to take the decisions for decision makers in the challenging scenarios. The results showed that they consider key elements of mcdm methods for accomplishing the target of sustainability in rising nations. Zavadskas et al. [5] performed the survey of sustainability issues and their applications by using mcdm methods. The findings of the paper depicts that for the issues in sustainability and future scope, the objective of the paper is to recognizing hybrid methods for enhancements in decision making. Shankar et al. [6] examined the sustainability risks in manufacturing industries by using DEMATEL methods and also case study is conducted. From the above study, 22 risks are identified from the literature review and they promote the concept of $6 \mathrm{R}$ for the effective implementation of sustainability in manufacturing industries. Shen et al. [7] analysed the risks in sustainability and also the development of sustainability in the mining sector by using AHP technique. The outcome of the study demonstrates that planning and environmental policy is the major risks in the sector and they need to control or eliminating the risks. Zavadsakas et al. [8] investigated the risk factors of sustainability in construction sector by using DANP method. Sustainable materials, planning and design in infrastructure are the most influencing factors and they need to implement them for the effective sustainability. Bhalaji et al. [9] examined the factors regarding environment in the healthcare firm by using Fuzzy DEMATEL technique. The findings showed that factory age is the most influencing factor in the process and they suggest for the firm to buy advanced machines and equipment for clean environment and customer satisfaction.

Published By: 


\section{B. Supply Chain}

Abdel-Basset [10] assessed the supply chain risks and makes a model for risk appraisal and management by using the method of neutrosophic TOPSIS and AHP. Interruption in production and warehousing plays a key role in the process and they need to control by such ways as start with the main region, effectively plan to control interruptions and communication. Chatterjee and kar [11] investigated the factors in supply chain and to select the supplier in the electronics industry by using modm methods like IVFS TOPSIS. The findings showed that supply, environmental and process risks are the critical part in the electronics industry and also the alternatives like most reliable suppliers acts as a major role. Govindan et al. [12] examined and ranking the risk factors for improving the performance in supply chain in the top four manufacturing sectors by using Fuzzy AHP and then results are validated with sensitivity analysis. Exchange of information and collaboration gets the top rank in the supply chain performance and the outcomes will be helpful for managers to understand the risks in the supply chain. Mangla et al. [13] analysed the barriers in supply chain process for accomplishing the sustainability in auto manufacturing industry by using Fuzzy AHP and then outcomes are compared with sensitivity analysis. Barriers in organization are the most influential one in the process for accomplishing the supply chain performance and they need to implement by some management standards. Chand et al. [14] conducted the risk assessment in Indian manufacturing industries for selecting the best risks regarding supply chain by using MOORA and ANP. The results demonstrated that financial risks are the best risks regarding supply chain and others are needed to improve it.

\section{Green supply chain}

Mangla et al. [15] created a framework with flexible decision for assessing green supply chain risks in plastic manufacturing firm by using mcdm methods such as IRP and Fuzzy AHP. Operational and supply risks are the critical zone in the process and these results will be used for managers from industries to eliminate or control the risks. Paksoy et al. [16] performed the risk assessment in green supply chain by using technique of fuzzy linguistic and Fuzzy ANP. For improving the business effectively, this paper will be surely helpful for industries based on the capability and flexibility of problems and also to determine the risk level and scores of the supplier are identified by using this method. Uygen and Dede [17] evaluated the green supply chain risks in the four various firms by using FDANP+TOPSIS. Transformation of green is the most influential one in the process and they need to implement by using some set of standards for green supply chain management. $\mathrm{Wu}$ and Chang [18] recognized the most influential risks of green supply chain in the Taiwan electrical industry by using DEMATEL technique. Based on the causal figure, management of supplier and involvement of organizations is the key factor in the process and also they took decisions for the risk factors for the effective implementation. Mangla et al. [19] examined the risks in green supply chain by using the method of Fuzzy AHP and then findings are authenticated with sensitivity analysis and also case study is conducted in poly-product manufacturing firms. The consequences demonstrate that risks in operation are the most influential one in the process.

\section{Waste Management}

Aung et al. [20] investigated the criteria for waste management system in Myanmar public hospital by using both ANP and AHP. The findings of the paper reveal that safe handling and disposal is the most influencing criteria and they need sufficient training to employees for both disposal and handling. Dursun [21] assessed the alternatives of waste water management in Istanbul healthcare industry by using Fuzzy VIKOR technique. From the above study, alternatives like sequential batch reactor and aerated lagoon acts as a major role in this process. Ciplak [22] conducted the assessment of waste management in the western sea zone of Turkish country by using MCDM method. The outcomes depict that technology with decentralized autoclaves is the most preferable option for waste management and they give more importance to the disposal by landfilling. Liu et al. [23] determined the best technology of waste treatment process in Chinese manufacturing industry by using Fuzzy MULTIMOORA method. Microwave and steam sterilization are the best technology in the process and they give more importance for this method and need to implement it for avoiding error.

\section{E. Service Quality}

Akdag et al. [24] assessed the criteria for service quality of four different hospitals in Turkey and to find the best one in the process by using TOPSIS. The consequences demonstrate that satisfaction of patients is the most important one in the service quality process as well as Hospital B is the best one and also other hospitals are need to implement it. Lupo et al. [25] explored the factors of service quality and create a model for assessment in Sicily healthcare firm by using AHP. Knowledge and skill of managers to comprehend the needs of customer, dependability of employees and responsiveness are the vital factors in this process. Singh and Prasher [26] quantifying the service quality risk factors from the patients point of view in the Punjab hospitals and to find the best one in the process based on the priority wise by using Fuzzy AHP. The results showed that reliability is the critical factor with weightage of $30 \%$ and Hospital $\mathrm{C}$ is the best one with the weightage of $34 \%$. Singh et al. [27] evaluated the parameters of service quality from both employees and customer point of view in the healthcare sector by using Fuzzy AHP. Responsiveness and empathy plays a key role in the process and they required comprehending the expectation of customer.

\section{F. Other areas}

Mohammed et al. [28] analysed the factors to select the sustainable supplier and allocation of order by deliberating the parameters of social, economic and environmental by using Fuzzy TOPSIS and AHP. Health and safety of employees and production of pollution is critical factor in the process and supplier 2 is the best sustainable supplier based on the parameters. Bathrinath et al. [29] investigated the factor for agile manufacturing by using DEMATEL technique and also case study is conducted in the

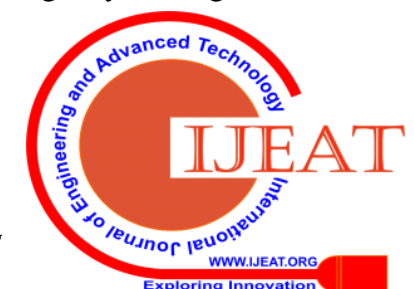


department of assembly in metal fabrication industry.

The consequences of the study depicts that satisfaction of customer is the most influential one and they need to implement for high production efficiency. Govindan and Chaudhuri [30] examined the risks handled by 3PLs (3rd party logistic service providers) and also to find the interrelations between customer by using DEMATEL. Relationship among customer and 3PLs has more impact on further risks and they required strong relationship between them and also they required to enhance reliability and management quality. Luthra et al. [31] explored the drivers and created a replica for adoption of production and sustainable consumption in the automotive manufacturing firm by using grey DEMATEL technique. Based on the causal figure, support from management, contribution, and commitment and also the rules and regulations of government are the critical drivers in the process. Rostamzadeh et al. [32] analysed the risks of supply chain with sustainable in Iran petrochemical sector by using Fuzzy CRITIC-TOPSIS techniques. Production and supply risks with sustainable are the critical risks in the sector and they need to execute some set of standards for achieving the production efficiency. Thanki et al. [33] surveyed the criteria for affecting the implementation of green and lean manufacturing in Indian small and medium scale companies by using AHP and the also results are validated with sensitivity analysis. Emission reductions and delivery on time plays a vital role in the implementation of green and lean and these results will help to implement the both manufacturing process.

\section{ANALYSIS OF RISKS}

From the review, process industry have $40 \%$ of risks occurred in sustainability issues and therefore more consideration should be given to these issues and for mainly to protect the environment as well as improving the finance. $25 \%$ of risks happened in waste management and they need proper training for waste disposal, segregation and storage. Supply chain has a risk percentage of about $15 \%$ and they need to implement supply chain management system and standards and also risk percentage of other areas is $10 \%$. Both green supply chain and service quality has a risk percentage of $5 \%$ and they need to understand the customer satisfaction and expectations and it is demonstrated in Table 7. Figure 1 shows the pie chart for the risk percentage.

\section{CONCLUSION}

The outcomes of the review paper reveal that process industry has more risk factors compared to others. Due to poor management system, each and every year risk factors are continuously increasing. This paper reviewed to identify the most influential risks in the process industry such as sustainability, supply chain, waste management, green supply chain, service quality and other areas by using MCDM methods. In this industry, many employees have poor skills and knowledge related to risk factors and they need training for understanding about the risk factors and creating awareness between them for managing the risks. To overcome this issue, we prioritize the risks based on the risk percentage it will surely help the employees and managers to know about the risk, avoidance of errors in the process as well as ready to take preventive actions before the risk will happen. The findings of the paper reveal that sustainability risk is the most influential risk with a risk percentage of $40 \%$. Based on the risk percentage, industry can implement management system, some set of standards and technologies for eliminating or controlling the risks. As per the rules and regulations of government, the industry provides some additional facilities for protecting the health and safety of the employees. There are some limitations in the paper and it can be explored in the future studies. This paper only reviewed 30 papers based on the following risks such as sustainability, supply chain, waste management, green supply chain and service quality. In future, more no of papers will be reviewed based on different risks. Based on the MCDM method this paper reviewed, in the future perspective more no of paper reviewed by using different conventional methods.

\section{REFERENCES}

1. J. Reason, "Managing the risks of organizational accidents," Routledge, 2016.

2. A. Mardani, A. Jusoh, K. Nor, Z. Khalifah, N. Zakwan and A. Valipour, "Multiple criteria decision-making techniques and their applications-a review of the literature from 2000 to 2014," Economic Research-Ekonomska Istraživanja, Vol. 28(1), 2015, 516-571.

3. E. K. Zavadskas, Z. Turskis and S. Kildiene, "State of art surveys of overviews on MCDM/MADM methods," Technological and economic development of economy, Vol. 20(1), 2014, 165-179.

4. A. Kumar, B. Sah, A. R. Singh, Y. Deng, X. He, P. Kumar and R. C. Bansal, "A review of multi criteria decision making (MCDM) towards sustainable renewable energy development," Renewable and Sustainable Energy Reviews, Vol. 69, 2017, 596-609.

5. E. Zavadskas, J. Šaparauskas and J. Antucheviciene, "Sustainability in construction Engineering," 2018.

6. K. M. Shankar, D. Kannan and P. U. Kumar, "Analyzing sustainable manufacturing practices-A case study in Indian context," Journal of cleaner production, Vol. 164, 2017, 1332-1343.

7. L. Shen, K. Muduli and A. Barve, "Developing a sustainable development framework in the context of mining industries: AHP approach," Resources Policy, Vol. 46, 2015, 15-26.

8. E. K. Zavadskas, K. Govindan, J. Antucheviciene and Z. Turskis, "Hybrid multiple criteria decision-making methods: A review of applications for sustainability issues," Economic research-Ekonomska istraživanja, Vol. 29(1), 2016, 857-887.

9. R. K. A. Bhalaji, S. Bathrinath, S. G. Ponnambalam and S. Saravanasankar, "A Fuzzy Decision-Making Trial and Evaluation Laboratory approach to analyse risk factors related to environmental health and safety aspects in the healthcare industry," Sādhanā, Vol. 44(3), 2019, 55.

10. M. Abdel-Basset, M. Gunasekaran, M. Mohamed and N. Chilamkurti, "A framework for risk assessment, management and evaluation: Economic tool for quantifying risks in supply chain," Future Generation Computer Systems, Vol. 90, 2019, 489-502.

11. K. Chatterjee and S. Kar, "Multi-criteria analysis of supply chain risk management using interval valued fuzzy TOPSIS," Opsearch, Vol 53(3), 2019, 474-499.

12. K. Govindan, S. K. Mangla and S. Luthra "Prioritising indicators in improving supply chain performance using fuzzy AHP: insights from the case example of four Indian manufacturing companies," Production Planning \& Control, Vol. 28(6-8), 2017, 552-573.

13. S. K. Mangla, K. Govindan and S. Luthra, "Prioritizing the barriers to achieve sustainable consumption and production trends in supply chains using fuzzy Analytical Hierarchy Process," Journal of cleaner production, Vol. 151, 2017, 509-525.

14. M. Chand, T. Raj, R. Shankar and A. Agarwal, "Select the best supply chain by risk analysis for Indian industries environment using MCDM approaches," Benchmarking: An International Journal, Vol. 24(5), 2017, 1400-1413.

15. S. K. Mangla, P. Kumar and M. K. Barua, "Flexible decision modeling for evaluating the risks in green supply chain using fuzzy AHP and IRP methodologies," Global Journal of Flexible Systems Management, Vol. 16(1), 2015, 19-35.

16. T. Paksoy, A. Çalik, A. Yildizbaşi and S. Huber, "Risk 
management in lean \& green supply chain: A novel fuzzy linguistic risk assessment approach," In Lean and Green Supply Chain Management (pp. 75-100). Springer, Cham, 2019.

17. O. Uygun and A. Dede, "Performance evaluation of green supply chain management using integrated fuzzy multi-criteria decision making techniques," Computers \& Industrial Engineering, Vol. 102, 2016, 502-511.

18. H. H. Wu and S. Y. Chang, A case study of using DEMATEL method to identify critical factors in green supply chain management. Applied Mathematics and Computation, 256, 394-403

19. S. K. Mangla, P. Kumar and M. K. Barua, "Risk analysis in green supply chain using fuzzy AHP approach: A case study," Resources, Conservation and Recycling, Vol. 104, 2015, 375-390.

20. T. S. Aung, S. Luan and Q. Xu, "Application of multi-criteria-decision approach for the analysis of medical waste management systems in Myanmar," Journal of Cleaner Production, 2019.

21. M. Dursun, "Evaluation of wastewater treatment alternatives using fuzzy VIKOR method," Journal of Advanced Management Science, Vol. 4(4), 2016

22. N. Ciplak, "Assessing future scenarios for health care waste management using a multi-criteria decision analysis tool: A case study in the Turkish West Black Sea Region," Journal of the Air \& Waste Management Association, Vol. 65(8), 2015, 919-929.

23. H. C. Liu, J. X. You, C. Lu and Chen, Y. Z. (2015). Evaluating health-care waste treatment technologies using a hybrid multi-criteria decision making model. Renewable and Sustainable Energy Reviews, 41, 932-942.

24. H. Akdag, T. Kalaycı, S. Karagöz, H. Zülfikar and D. Giz, "The evaluation of hospital service quality by fuzzy MCDM," Applied Soft Computing, Vol.23, 2014, 239-248.

25. T. Lupo, "A fuzzy framework to evaluate service quality in the healthcare industry: An empirical case of public hospital service evaluation in Sicily," Applied Soft Computing, Vol. 40, 2016 468-478.

26. A. Singh and A. Prasher, "Measuring healthcare service quality from patients' perspective: using Fuzzy AHP application," Total Quality Management \& Business Excellence, Vol.30(3-4), 2019, 284-300.

27. A. Singh, A. Prasher and N. Kaur, "Assessment of hospital service quality parameters from patient, doctor and employees' perspectives,' Total Quality Management \& Business Excellence, 2018, 1-20.

28. A. Mohammed, I. Harris and G. Kannan, "A hybrid MCDM-FMOO approach for sustainable supplier selection and order allocation," International Journal of Production Economics, 2019.

29. S. Bathrinath, V. S. Charan, S. G. Ponnambalam and S> Saravanasankar, "Identification and Evaluation of Criteria of Agile Manufacturing Using DEMATEL: A Case from an Indian Metal Fabrication Industry," Journal of Modern Manufacturing Systems and Technology, Vol. 2(1), 2019, 61-74.

30. K. Govindan and A. Chaudhuri, "Interrelationships of risks faced by third party logistics service providers: A DEMATEL based approach," Transportation Research Part E: Logistics and Transportation Review, Vol. 90, 2016, 177-195.

31. S. Luthra, K. Govindan and S. K. Mangla, "Structural model for sustainable consumption and production adoption-A grey-DEMATEL based approach," Resources, Conservation and Recycling, Vol. 125, 2017, 198-207.

32. R. Rostamzadeh, M. K. Ghorabaee, K. Govindan, A. Esmaeili and H B. K. Nobar, "Evaluation of sustainable supply chain risk management using an integrated fuzzy TOPSIS-CRITIC approach,' Journal of cleaner production, Vol. 175, 2018, 651-669.

33. S. Thanki, K. Govindan and J. Thakkar "An investigation on lean-green implementation practices in Indian SMEs using analytical hierarchy process (AHP) approach," Journal of Cleaner Production, Vol. 135, 2016, 284-298.

\section{AUTHORS PROFILE}

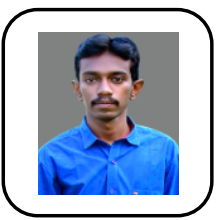

R.K.A.Bhalaji obtained his B.E (MECH) in 2014 from the K.L.N.College of Engineering, Madurai, Tamilnadu, India. He completed his M.Tech (Industrial Safety Engineering) in 2016 at the Kalasalingam Academy of Research and Education, Krishnankoil, Tamilnadu, India. Currently, he is a Research Scholar in the Department of Mechanical Engineering, Kalasalingam Academy of Research and Education, Krishnankoil, Tamilnadu, India. His research interests include multi-criteria decision making and application of fuzzy set theory in real life decision problems. He is currently pursuing PHD in the area of analysis of risk factors for the identification and evaluation for finding influential risk factors in healthcare industries by using MCDM methods.

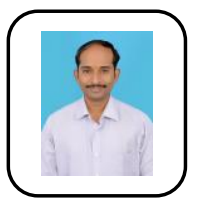

Dr.S.Bathrinath is an Associate Professor in the Department of Mechanical Engineering, Kalasalingam Academy of Research and Education, Krishnankoil, Tamilnadu, India. His current area of research includes multi-criteria decision making, scheduling \&

optimization, soft computing and Artificial intelligence. $\mathrm{He}$ has published a number of papers in journal of national/international repute and presented a number of papers in various conferences/symposia in India and abroad. He is presently guiding a number of master/doctoral research scholars. Dr.S.Bathrinath is the corresponding author and can be contacted at bathri@gmail.com

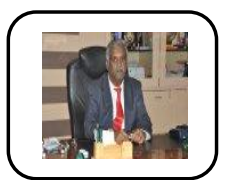

Dr.S.Saravanasankar is a Senior Professor in the Department of Mechanical Engineering, Kalasalingam Academy of Research and Education, Krishnankoil, Tamilnadu, India. He has more than 20 years of experience in teaching and research. His current area of research includes scheduling, optimization and multi-criteria decision making He has published more than 40 research articles in journals of national and international repute.

Table- VII: Risk percentage for the following risks

\begin{tabular}{|c|c|}
\hline Risks & Risk percentage \\
\hline Sustainability & $40 \%$ \\
\hline Waste Management & $25 \%$ \\
\hline Supply Chain & $15 \%$ \\
\hline Service quality & $5 \%$ \\
\hline Other areas & $10 \%$ \\
\hline Waste management & $5 \%$ \\
\hline
\end{tabular}

\section{Risk percentage}

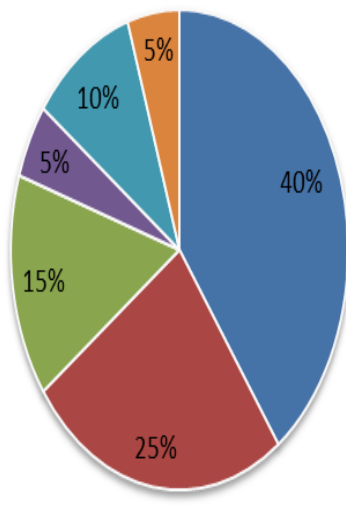

- Sustainability

- Waste Management

Supply Chain

- Service quality

Other areas

Waste management

Fig. 1. Pie chart for the risk percentage 
Table- I: Summary of sustainable risks in process industry

\begin{tabular}{|l|l|l|l|}
\hline \multicolumn{1}{|c|}{ Author } & \multicolumn{1}{|c|}{ Method } & & Objective \\
\hline Kumar et al., (2017) & MCDM & Review for sustainability development for the effective implementation & $\begin{array}{l}\text { For achieving the target in sustainability, they consider some key elements of } \\
\text { mcdm methods. }\end{array}$ \\
\hline Zavadskas et al., (2016) & MCDM & Survey of sustainability issues and their applications & $\begin{array}{l}\text { For the improvements in decision making and sustainability, they identified } \\
\text { hybrid approaches. }\end{array}$ \\
\hline Shankar et al., (2017) & DEMATEL & Analyze sustainable risks in manufacturing sectors & Promotes 6R concepts for the effective implementation of sustainability \\
\hline Shen et al., (2015) & AHP & Analyze the risks and develop the sustainability in mining industry & $\begin{array}{l}\text { Environmental policy and planning are the most influencing one and they need } \\
\text { to diminish them. }\end{array}$ \\
\hline Zavadsakas et al., (2018) & DANP & Examine the risks in construction sector & $\begin{array}{l}\text { Planning, design and sustainable materials plays a key role and they required to } \\
\text { implement. }\end{array}$ \\
\hline Bhalaji et al., (2019) & Fuzzy DEMATEL & Evaluated the environmental risk factors in healthcare sector & $\begin{array}{l}\text { Factory age is the critical factor and they need to implement by buying advanced } \\
\text { machines. }\end{array}$ \\
\hline
\end{tabular}

Table- II: Summary of supply chain risks in process industry

\begin{tabular}{|l|l|l|l|}
\hline \multicolumn{1}{|c|}{ Author } & \multicolumn{1}{|c|}{ Method } & \multicolumn{1}{|c|}{ Objective } & \multicolumn{1}{|c|}{ Consequences } \\
\hline Abdel-Basset (2019) & TOPSIS and AHP & $\begin{array}{l}\text { Investigated the risks in supply chain and to create a model for risk appraisal and } \\
\text { management }\end{array}$ & $\begin{array}{l}\text { Interruption in production and warehousing act as a key role and they need to } \\
\text { control by some ways }\end{array}$ \\
\hline Chatterjee and kar (2016) & IVFS TOPSIS & $\begin{array}{l}\text { Examine the supply chain risk factors and also the supplier selection in the } \\
\text { electronics industry }\end{array}$ & $\begin{array}{l}\text { Most influential risks are supply, environmental and process as well as most } \\
\text { reliable supplier is the primary alternative }\end{array}$ \\
\hline Govindan et al., (2017) & Fuzzy AHP & $\begin{array}{l}\text { Ranking the risk factors for the supply chain performance in the manufacturing } \\
\text { sector }\end{array}$ & $\begin{array}{l}\text { Exchange of information and collaboration gets the first rank and it will be } \\
\text { helpful for managers for controlling the risks }\end{array}$ \\
\hline Mangla et al., (2017) & Fuzzy AHP & $\begin{array}{l}\text { Analyzing the barriers in supply chain process for accomplishing sustainability in } \\
\text { auto manufacturing industry }\end{array}$ & $\begin{array}{l}\text { Organizational barriers are the most influential one and they need to implement } \\
\text { them. }\end{array}$ \\
\hline Chand et al., (2017) & MOORA and ANP & To choose the best risks regarding supply chain in manufacturing firm & Based on the outcomes, financial risks is the best one \\
\hline
\end{tabular}

\begin{tabular}{|l|l|l|}
\hline \multicolumn{1}{|c|}{ Author } & \multicolumn{1}{|c|}{ Method } \\
\hline Mangla et al., (2015) & $\begin{array}{l}\text { IRP and Fuzzy } \\
\text { AHP }\end{array}$ & \\
\hline Paksoy et al., (2019) & Fuzzy ANP & Ri \\
\hline
\end{tabular}

Table- III: Summary of green supply chain risks in process industry

\begin{tabular}{|l|l|}
\hline \multicolumn{1}{|c|}{ Objective } & \multicolumn{1}{c|}{ Consequences } \\
\hline Make a model with flexible decision for assessing green supply risks & $\begin{array}{l}\text { Operational and supply risks play a major role in the process and they need to } \\
\text { control it. }\end{array}$ \\
\hline Risk assessment in green supply chain & $\begin{array}{l}\text { Risk level and scores are determined and the results will be helpful for } \\
\text { improving the business effectively. }\end{array}$ \\
\hline
\end{tabular}


Risk factors in the process industry by using MCDM methods: Literature from 2014 to 2019

\begin{tabular}{|c|c|c|c|}
\hline Uygen and Dede (2016) & FDANP+TOPSIS & Investigated the green supply chain risks in four varied firms & $\begin{array}{l}\text { Transformation of green is the most influential one and they required to } \\
\text { implement by using green standards. }\end{array}$ \\
\hline Wu and Chang (2015) & Fuzzy DEMATEL & $\begin{array}{l}\text { In the Taiwan electrical industry, to recognize the critical factors of green supply } \\
\text { chain process }\end{array}$ & $\begin{array}{l}\text { Involvement of organizations and management of supplier are the major part in } \\
\text { the process. }\end{array}$ \\
\hline Mangla et al., (2015) & Fuzzy AHP & In the poly-product manufacturing firms to analyse the green supply chain risks & Operational risks play a vital role. \\
\hline
\end{tabular}

\begin{tabular}{|c|c|c|c|}
\hline Author & Method & Objective & Consequences \\
\hline Aung et al., (2019) & ANP and AHP & Evaluated the criteria for waste management in Myanmar public hospital & $\begin{array}{l}\text { Safe disposal and handling is the critical one in this process and they required } \\
\text { training to employees }\end{array}$ \\
\hline Dursun (2016) & Fuzzy VIKOR & Investigated the alternatives of waste management in Istanbul healthcare industry & Aerated lagoon and sequential batch reactor plays a vital role in the industry \\
\hline Ciplak (2015) & MCDM & Waste management assessment in western part of sea in Turkish country & $\begin{array}{l}\text { Technology with decentralized autoclaves is the best option in waste } \\
\text { management }\end{array}$ \\
\hline Liu et al., (2015) & $\begin{array}{l}\text { Fuzzy } \\
\text { MULTIMOORA }\end{array}$ & Find the best technology of waste treatment in Chinese manufacturing firm & Steam sterilization is the best treatment \\
\hline
\end{tabular}

\begin{tabular}{|c|c|c|c|}
\hline Author & Method & Objective & Consequences \\
\hline Akdag et al., (2014) & TOPSIS & $\begin{array}{l}\text { Evaluated the service quality criteria in Turkey hospitals and to determine the best } \\
\text { one }\end{array}$ & $\begin{array}{l}\text { Patients satisfaction is the vital one as well as Hospital B is the best one in the } \\
\text { process }\end{array}$ \\
\hline Lupo et al., (2016) & AHP & Investigated the factors of service quality in Sicily healthcare firm & $\begin{array}{l}\text { Responsiveness and dependability of staff as well as knowledge and skill of } \\
\text { managers to understand the customer expectation is the key one }\end{array}$ \\
\hline Singh and Prasher (2019) & Fuzzy AHP & $\begin{array}{l}\text { Evaluated the service quality elements from the patients point of view in Punjab } \\
\text { hospitals and to find the best one }\end{array}$ & $\begin{array}{l}\text { Reliability is the critical element as well as Hospital } \mathrm{C} \text { is the best one in the } \\
\text { process. }\end{array}$ \\
\hline Singh et al., (2018) & Fuzzy AHP & $\begin{array}{l}\text { Assessed the parameters of service quality from the customer and employees point of } \\
\text { view }\end{array}$ & Empathy and responsiveness is the key one in the service quality \\
\hline
\end{tabular}

\begin{tabular}{|l|l|l|}
\hline Author & Method & \\
\hline Mohammed et al., (2019) & $\begin{array}{l}\text { Fuzzy } \\
\text { TOPSIS-AHP }\end{array}$ & \\
\hline Bathrinath et al., (2019) & DEMATEL & Fo \\
\hline
\end{tabular}

Table- VI: Summary of other risks in process industry

\begin{tabular}{|l|l|}
\hline Objective & Consequences \\
\hline $\begin{array}{l}\text { For achieving the high production efficiency, investigated the risks of agile } \\
\text { manufacturing in metal manufacturing industry }\end{array}$ & $\begin{array}{l}\text { Employees health and safety, production of pollution is the most influential risks } \\
\text { and supplier 2 is the finest sustainable supplier }\end{array}$ \\
$\begin{array}{l}\text { Satisfaction of customer is the critical one in the process and they need to } \\
\text { implement it }\end{array}$ \\
\hline
\end{tabular}

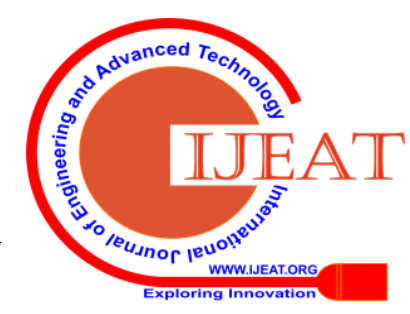


International Journal of Engineering and Advanced Technology (IJEAT) ISSN: 2249 - 8958, Volume-9 Issue-1S4, December 2019

\begin{tabular}{|c|c|c|c|}
\hline Govindan and Chaudhuri (2016) & DEMATEL & Analysing the 3PLs risks and their interrelationship between customer & $\begin{array}{l}\text { They required robust relationship between both 3PLs and customer as well to } \\
\text { improve reliability and quality of management }\end{array}$ \\
\hline Luthra et al., (2017) & Grey DEMATEL & Investigated the drivers and make a model for sustainable consumption & $\begin{array}{l}\text { Communication, commitment, support from top management and rules and } \\
\text { regulations of employees are the critical drivers }\end{array}$ \\
\hline Rostamzadeh et al., (2018) & $\begin{array}{l}\text { Fuzzy } \\
\text { CRITIC-TOPSIS }\end{array}$ & Examined the sustainable supply chain risks in petrochemical sector & Sustainable supply and production risks plays a vital role \\
\hline Thanki et al., (2016) & AHP & $\begin{array}{l}\text { In small and medium scale companies, analysed the risks for affecting green and lean } \\
\text { implementation }\end{array}$ & Emission reduction and delivery on time act as a key part \\
\hline
\end{tabular}

